\title{
Secreted Frizzled-Related Protein 2
}

National Cancer Institute

\section{Source}

National Cancer Institute. Secreted Frizzled-Related Protein 2. NCI Thesaurus. Code C105003.

Secreted frizzled-related protein 2 (295 aa, $\sim 33 \mathrm{kDa}$ ) is encoded by the human SFRP2 gene. This protein is involved in regulating cell growth and differentiation as a modulator of Wnt signaling. 